\title{
In Vivo Level of Poly(ADP-ribose)
}

\author{
Masanao Miwa ${ }^{1, *}$, Chieri Ida ${ }^{2}$, Sachiko Yamashita ${ }^{1}$, Kenichi Kouyama ${ }^{1}$, Yasuhito Kuroda ${ }^{1}$, \\ Takayuki Eguchi ${ }^{1}$, Narumi Ohta ${ }^{1}$, Teruaki Sato ${ }^{1}$, Masataka Tsuda ${ }^{3}$ and Masakazu Tanaka ${ }^{4}$ \\ 1 Nagahama Institute of Bio-Science and Technology, Nagahama, Shiga 526-0829, Japan; \\ yama_chiko3523@yahoo.co.jp (S.Y.); kno1white@yahoo.co.jp (K.K.); ykuroda@stemcell.co.jp (Y.K.); \\ 0ft388133245.7u@ezweb.ne.jp (T.E.); narumi.ota.1416@gmail.com (N.O.); exceed_teru@yahoo.co.jp (T.S.) \\ 2 Department of Applied Life Sciences, College of Nagoya Women's University, Nagoya-shi, Aichi 467-8610, \\ Japan; ishizaki@nagoya-wu.ac.jp \\ 3 Department of Mathematical and Life Sciences, Graduate School of Science, Hiroshima University, \\ Higashi-Hiroshima, Hiroshima 739-0046, Japan; mibr10565@yahoo.co.jp \\ 4 Center for Chronic Viral Diseases, Kagoshima University, Sakuragaoka 8-35-1, Kagoshima 890-8544, Japan; \\ tanakam@m.kufm.kagoshima-u.ac.jp \\ * Correspondence: m_miwa@nagahama-i-bio.ac.jp
}

Received: 10 April 2018; Accepted: 18 May 2018; Published: 22 May 2018

\begin{abstract}
PolyADP-ribosylation is a post-translational modification that plays key roles in cellular physiological functions and DNA damage responses. PolyADP-ribosylation is finely and dynamically regulated by various enzymes and factors involved in the synthesis and degradation of poly(ADP-ribose) (PAR). To better understand the function of polyADP-ribosylation, it is necessary to quantify and monitor the change of the in vivo level of PAR, the product of polyADP-ribosylation, which is rapidly turning over and kept in quite low level in cells or in organs. Recent developments of potent inhibitors of polyADP-ribosylation is expected to kill BRCA1/2-mutated breast cancer cells and ovarian cancer cells (synthetic lethality). To know the efficacy of these inhibitors in vivo, it is necessary to develop highly sensitive and reproducible methods to know PAR levels within cells or organs. However there have been several difficulties in measuring the physiologically low level of PAR without artefacts. Our experiments recently clarified that the method of sample preparation is very important in addition to the sensitivity and specificity. From reviewing the literature, including ours, we would like to emphasize the importance of the procedures of sample preparation for the assay, in addition to the sensitivity by comparing the reported PAR levels in vivo.
\end{abstract}

Keywords: polyADP-ribosylation; poly(ADP-ribose); PARP; PARG; PARP inhibitor; radioimmunoassay; ELISA; LC-MS/MS

\section{Introduction}

\subsection{What Is PolyADP-Ribosylation?}

PolyADP-ribosylation is a post-translational modification that adds a long polymer of poly(ADP-ribose) (PAR) chain to the acceptor proteins [1,2]. The enzymes, PAR polymerases (PARPs, also named ADP-ribosyltransferases-diphtheria toxin-like (ARTDs) [3]) and ADP-ribosyl transferase 2 (ART2), are responsible for synthesis of PAR attached to acceptor proteins using $\beta \mathrm{NAD}^{+}$as the substrate [4-7]. On the other hand, PAR glycohydrolase (PARG) and ADP-ribosyl hydrolase 3 (ARH3) can degrade the PAR polymer from acceptor proteins [8-10]. Finally, ADP-ribosyl protein lyase, macrodomain-containing proteins, terminal ADP-ribose protein glycohydrolase 1 (TARG 1) and ARH3 can remove the proximal ADP-ribose residue from the acceptor protein [11-14] (Figure 1). There are monoADP-ribosylation reaction and polyADP-ribosylation reaction, and they are collectively termed 
"ADP-ribosylation reaction", catalyzed by enzymes widely found in animals, plants and bacteria using $\mathrm{NAD}^{+}$[15]. However, this article is intended to emphasize the importance of measuring the actual amount of PAR found in vivo and to discuss the methods and the resulting PAR levels in vivo.

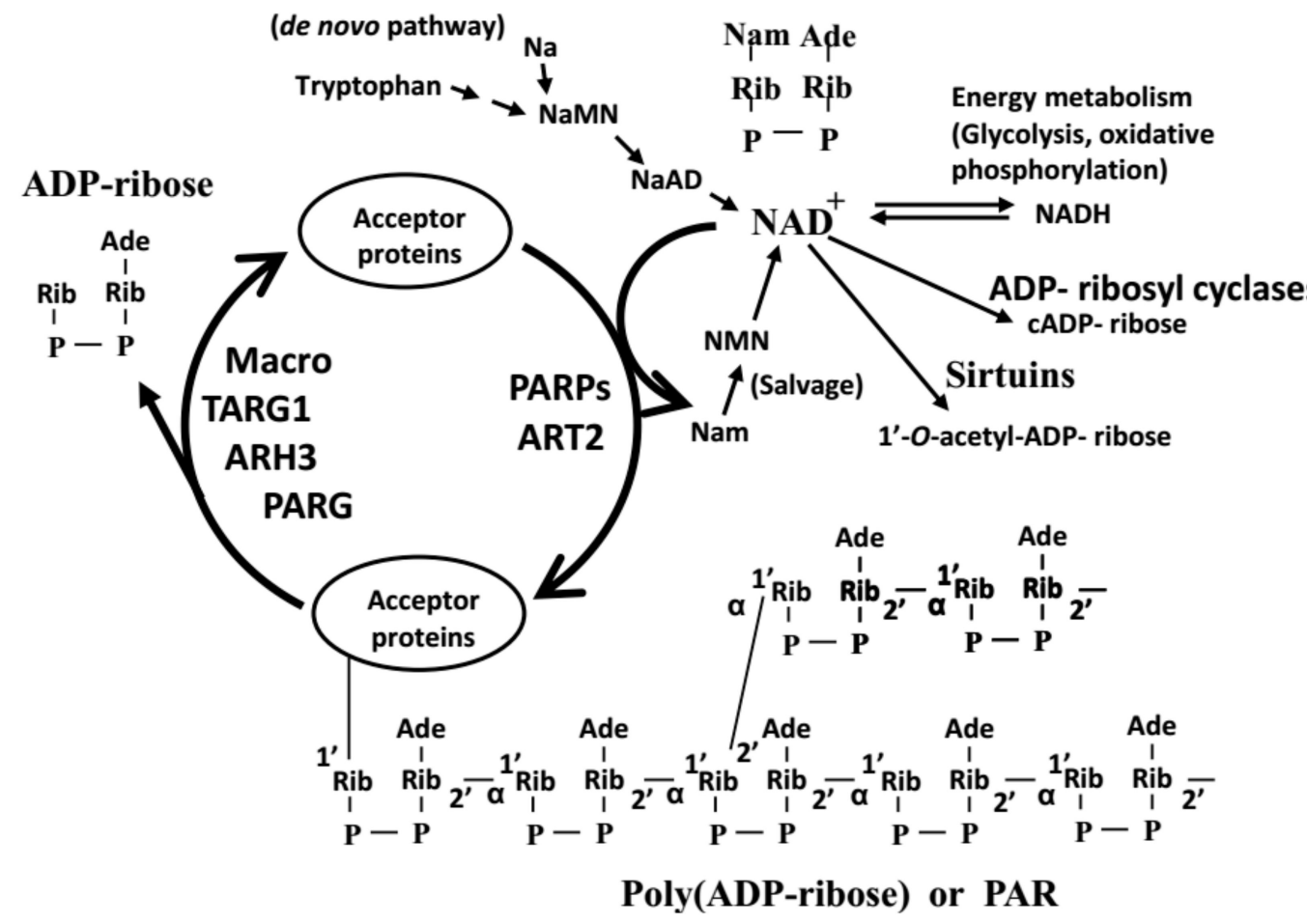

Figure 1. PolyADP-ribosylation reaction. ARH3: ADP-ribosylhydrolase 3; ART2: ADP-ribosyltransferase 2; Macro: macrodomain-containing proteins; Na: nicotinic acid; Nam: nicotinamide; NaMN: nicotinic acid mononucleotide; NMN: nicotinamide mononucleotide; NaAD: nicotinic acid adenine dinucleotide; PAR: poly(ADP-ribose); PARG: poly(ADP-ribose) glycohydrolase; PARPs: poly(ADP-ribose) polymerases; TARG1: Terminal ADP-ribose protein glycohydrolase 1.

\subsection{Proposed Functions of PolyADP-Ribosylation}

There have been many excellent reviews, including historical ones, on polyADPribosylation [1,2,16-22]. On the biological functions of polyADP-ribosylation, various works in vitro and in vivo have been reported using inhibitors of polyADP-ribosylation, gene-knockout animals of responsible enzymes or in vitro experiments with purified PARPs or PARG [23-27]. They include base-excision DNA repair [28], DNA replication [29,30], transcription [20,31,32], chromatin remodeling [33,34], sister chromatid exchanges [35,36], centrosome number regulation [37], telomere regulation [38], cell signaling [39-42], cell proliferation [23], carcinogenesis [43], neurodegeneration [12,26], immunological defense [23,44], hypoxia and reperfusion damage [45], and cell death [44,46].

There are two types of functions played by polyADP-ribosylation. One is that since polyADP-ribosylation is a modification of the acceptor proteins, the function of the acceptor proteins could be changed significantly in their enzyme activities and the interaction with other proteins. The acceptor proteins in vitro reaction include PARP1, histone $\mathrm{H} 1$, histone $\mathrm{H} 2 \mathrm{~b}$, RNase and TP53 [40,47-51] and the number of acceptor molecules is still increasing.

The other is that the attached PAR polymer has a big size with large negative charges. Chemical analysis showed that PAR has branched structure [52]. Consistent with this finding, electron micrography showed that the synthesized PAR had a branched shape $[53,54]$. The diameter of some of the PAR reached 200-300 nm in length. Althaus and his colleagues noticed and proposed that a free PAR chain is bound non-covalently by specified proteins including histones, and involved in the regulation of biological functions $[55,56]$. In fact, following modules or motifs that recognize specific 
structures of PAR have been found including PAR binding motif (PBM), macrodomain motif, PAR binding zinc finger (PBZ), WWE domain and OB fold domain [21,57-62]. It is likely that PAR functions as a scaffold for macromolecules to support various biological activities.

\subsection{Importance to Understand the In Vivo Level of PAR that is Rapidly Turning-Over under Various Biological Conditions}

As shown in Figure 1, polyADP-ribosylation is regulated by enzymes involved in the synthesis and degradation of PAR. In addition, as shown by many investigations, the activities of PARP1 or PARP2 is greatly enhanced by the presence of DNA strand breaks [19]. The interaction of PARP1 or PARP2 with other proteins could also regulate the activities of the proteins. For example, the phosphorylated ERK1/2 protein, one of the important cellular signal transduction factors, could stimulate PARP1 enzyme activity without any involvement of DNA [39]. It is also noticed that PAR is rapidly degraded by PARG. Thus, measuring the amount of the specified enzymes or their activities are not enough to understand the polyADP-ribosylation status, and the measurement of the level of PAR, rapidly turning over in physiological conditions, should be measured as a more accurate marker. As are the characteristics of most of the post translational modifications, the speed of changes of the PAR level is quite rapid, being less than 1 min (unpublished). There are about $10^{6}$ molecules of PARP1, the most abundant and well-studied member of PARP family present in a cell [32]. However, the level of PAR, the reaction product of PARP1, is considerably low, suggesting the necessity of tight and efficient method of regulation of PAR in vivo. For determining the PAR levels in vivo, under unstressed conditions (i.e., without exogenous DNA damaging agents), western blot analysis is not sensitive enough. Many researchers have frequently experienced the situation that the physiological level of PAR is difficult to show by western blot. Artificial synthesis of PAR could occur presumably due to uncontrollable DNA damages occurring during the procedures of cell lysis. Therefore, in addition to developing highly sensitive and specific assay methods, it is necessary to control the lysis conditions keeping the level of DNA damages that might occur during cell lysis and fixation processes before extraction of PAR minimal.

We will review efforts by various researchers including us to quantitate physiological levels of PAR without apparent exogenous DNA damaging agents to better understand the nature of polyADP-ribosylation and for clarification of its possible biological functions thus far unknown.

\subsection{Measurement of the Amount of PAR In Vivo (i.e., in Cells or Tissues)}

Although PAR is clearly observable as a smear by western blot analysis after treatment of exogenous DNA damaging agents, the level of PAR in unstressed conditions is quite low and difficult to show by western blot as stated in the previous section. Considering that PARP1 could be activated in the absence of DNA [39], it seems quite interesting to know other physiological functions of polyADP-ribosylation that are unrelated to the exogenous DNA damage and repair. There have been many works suggesting the physiological functions of polyADP-ribosylation using various kinds of PARP inhibitors. However, we do not know exactly how efficient these inhibitors worked in the cell. If the inhibition was not complete, it will cause confusions on the function of PARP1.

One of the difficulties of measuring the physiologically low level of PAR is due to the fact that the substrate of PARPs, $\mathrm{NAD}^{+}$, is impermeable through cell membranes and radioactive $\mathrm{NAD}^{+}$could not be used for efficient and sensitive labeling of the intracellular PAR. Therefor the precursors of $\mathrm{NAD}^{+}$, e.g., phosphate or adenine, have been used to prove the natural occurrence of PAR. Doly et al. injected $\left[{ }^{32} \mathrm{P}_{3} \mathrm{H}_{3} \mathrm{PO}_{4}\right.$ into chicken and isolated liver nuclei. Then, according to the procedure of purifying PAR, already known in vitro, they isolated and purified the PAR fraction and hydrolyzed it with snake venom phosphodiesterase (pyrophosphatase) and found Ado(P)-Rib-P, which is the specific hydrolysis product of PAR (Figure 2). This is the first indication that PAR is synthesized in vivo [63]. The other researchers used radiolabeled adenine to show the natural occurrence of PAR [64]. Subsequently, there have been several reports on the natural occurrence of PAR. Interestingly, naturally occurring antibody 
against PAR was found in the sera of patients with systemic lupus erythematosus, an autoimmune disease [65]. However, accurate quantitation of PAR has been facing various problems.

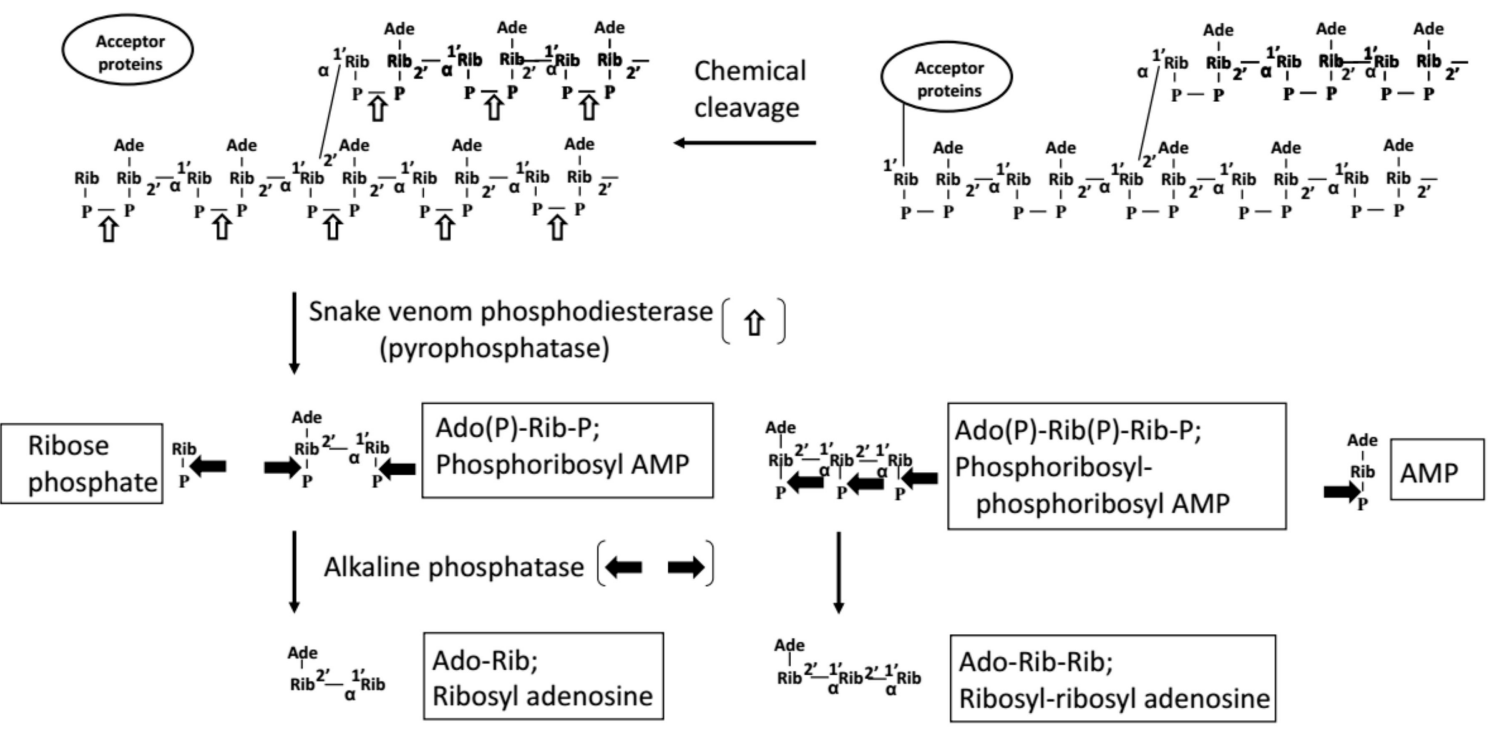

Figure 2. Specific degradation products of polyADP-ribosylation.

As shown in Table 1, Smith and Stocken reported that histone F1 purified from rat liver contained adenine, ribose, phosphate, and serine as $0.89,1.73,1.83$ and $0.31 \mathrm{nmol}$ per mg protein, respectively. They suggested that ADP-ribose was bound to histone F1 via serine or serine phosphate [66].

Then Stone et al. initially used orthodox isotope dilution methods to quantitate endogenous PAR as 5.59 and $6.32 \mathrm{nmol} / \mathrm{mg}$ DNA, for adult and neonatal rat liver, respectively [67] (Table 1). However, the amount of endogenous PAR seems significantly higher than that was reported in the later publication by the same research group $[68,69]$ (Table 1 ). This might be partly due to the procedure of calculating the specific activity of standard $\left[{ }^{3} \mathrm{H}\right] \mathrm{PAR} .\left[{ }^{3} \mathrm{H}\right] \mathrm{PAR}$ was synthesized from $\left[{ }^{3} \mathrm{H}\right] \mathrm{NAD}^{+}$ using the sonicated whole cell lysate of Ehrlich ascites carcinoma cells as the enzyme source that might have had already contained significant amount of unlabeled endogenous NAD ${ }^{+}$. These endogenous $\mathrm{NAD}^{+}$in the cell lysate might dilute the specific activity of the originally used $\left[{ }^{3} \mathrm{H}\right] \mathrm{NAD}^{+}$, making the specific activity of the standard [3H]PAR significantly lower than that of the originally used $\left[{ }^{3} \mathrm{H}\right] \mathrm{NAD}^{+}$. This should cause overestimation of endogenous PAR level.

Kidwell and Mage made rabbit polyclonal antibody against PAR with a mean chain length of 24 after the method by Kanai et al. [70] and developed a radioimmunoassay system to determine PAR levels in HeLa cells [71] (Table 1). They lysed cultured HeLa cells in $0.1 \mathrm{~N} \mathrm{NaOH}$ for $2 \mathrm{~h}$ at $37^{\circ} \mathrm{C}$, stored overnight at $4{ }^{\circ} \mathrm{C}$, neutralized, treated with DNase I and micrococcal nuclease, digested with Pronase and extracted PAR with phenol to be used for the assay. To confirm the specificity of their radioimmunoassay, they showed that the binding of $\left[{ }^{14} \mathrm{C}\right] \mathrm{PAR}$ to the antibody was inhibited with equal amount of unlabeled PAR by $50 \%$, but 25,000 -fold excess $(w / w)$ amount of poly(A), native DNA or denatured DNA did not show any appreciable inhibition. Neither $\mathrm{NAD}^{+}, \mathrm{NADP}^{+}, \mathrm{NADH}$ nor NADPH appreciably inhibited the binding when present in the binding assay with a 100,000-fold excess amount of radiolabeled PAR. With ADP-ribose present at a 10,000-fold excess, the binding of labeled PAR was inhibited by $30 \%$ and, at a 100,000-fold excess, the inhibition was nearly total. They also labeled cells with $\left[{ }^{14} \mathrm{C}\right]$ ribose and the materials which bound to the antibody was digested with snake venom phosphodiesterase and separated by Dowex-formate column chromatography. Then they isolated the radioactive compound, which was identified as Ado(P)-Rib-P by Dowex-formate column chromatography as well as PEI-cellulose thin layer chromatography. Using the above specificity of the antibody, they reported the endogenous level of PAR as $3.7 \mathrm{pmol} / 10^{6} \mathrm{HeLa}$ cells ( $200 \mathrm{ng} / 10^{8}$ cells) (Table 1$)$. Interestingly, there was a small peak of PAR at 
S phase and a large peak at G2 phase. However, the amount of endogenous PAR was about 100 times higher as compared to the report on HeLa cells by Martello et al. [72] or Ida et al. [73]. The reason for this discrepancy is not clear but might partly be due to the experimental condition to prepare the samples before the assay (discussed later).

Sakura et al. measured PAR with radioimmunoassay using calf thymus nuclei [74] (Table 1). They made rabbit polyclonal antibody against PAR with a mean chain length of 28 (it was later found that this PAR contained much higher molecular weight PAR with branches). In addition, using this polyclonal antibody they showed that there was an immunoreactive principle in the extract of calf thymus nuclei and its reactivity was lost by prior incubation with PARG or snake venom phosphodiesterase (pyrophosphatase), but not with DNase I, pancreatic RNase, nuclease $\mathrm{P} 1$, pronase $\mathrm{E}$ or $0.5 \mathrm{~N} \mathrm{NaOH}$ treatment for $18 \mathrm{~h}$ at $37^{\circ} \mathrm{C}$. This was consistent with the character of in vitro synthesized PAR, indicating that there is PAR in calf thymus. They also showed that calf thymus contained PAR with various chain length (molecular size) and that PAR with shorter chain length reacted less efficiently to the antibody, as was expected with authentic PAR with shorter chain length. However, by normalizing the immunoreactivity of PAR with shorter chain length, the total amount of PAR in calf thymus was estimated as $740 \mathrm{pmol}(0.4 \mu \mathrm{g}) / \mathrm{g}$ tissue or $37 \mathrm{pmol}$ $(0.02 \mu \mathrm{g}) / \mathrm{mg}$ DNA. Similar recovery of immunoreactivity was obtained when frozen calf thymus was homogenized directly in 5\% trichloroacetic acid (TCA), without isolating nuclei, and processed similarly. This result suggested that there was no significant degradation or synthesis of PAR in vitro during the step of isolation of nuclei.

In 1979, Juarez-Salinas et al. treated cultured cells with 20\% TCA, extracted PAR fraction and hydrolyzed PAR fraction with snake venom phosphodiesterase and alkaline phosphatase to isolate Ado-Rib (ribosyl adenosine), which is the dephosphorylated monomer form of PAR (Figure 2). Then they reacted this fraction with chloroacetaldehyde to make adenine residue to etheno adenine residue that is highly fluorescent. They separated these products with high performance liquid chromatography (HPLC) to show the presence of fluorescence-labeled etheno Ado-Rib, confirming the presence of PAR in vivo. Although the chain length distribution pattern of PAR could not be evaluated, this method could measure total amount of ADP-ribose residues constituting PAR quantitatively. In addition, they also showed that by treating the cultured cells with $N$-methyl- $N^{\prime}$-nitro- $N$-nitrosoguanidine (MNNG), a DNA damaging agent, the PAR level increased dramatically but rapidly decreased [75] (Table 1).

Wielkens et al. prepared rabbit polyclonal antibody against Ado(P)-Rib-P (phosphoribosyl AMP, or pseudoADP-ribose), the specific component of PAR (Figure 2). In addition, they made [3H]PAR of high specific activity from $\left[{ }^{3} \mathrm{H}\right] \mathrm{NAD}{ }^{+}$synthesized from $\left[{ }^{3} \mathrm{H}\right] \mathrm{ATP}$ and nicotinamide mononucleotide using Ehrlich ascites tumor cell nuclei, which did not seem to contain significant amount of ATP. By combining radioimmunoassay and tracer $\left[{ }^{3} \mathrm{H}\right] \mathrm{PAR}$, they extracted PAR by first freeze-clamped normal rat liver. They reported the PAR level as 72.6-128.1 pmol/g rat liver tissue [69] (Table 1). Bredehorst et al. in the same research group reported the PAR level as $32 \pm 9,10 \pm 2,39 \pm 5 \mathrm{pmol} / \mathrm{mg}$ DNA of neonatal (1 day), neonatal (17 days) and adult ( $>150$ days) rat liver, respectively. They also reported the PAR level in hepatoma cells as $61 \pm 11,25 \pm 3$ and $60 \pm 17$ pmol/mg DNA for AH130, AH 7974 and Reuber H35 hepatomas, respectively [68] (Table 1).

In 1982, Juarez-Salinas et al. using their fluorescence labeling technique [75] reported that 14, 18, and $8.0 \mathrm{pmol}$ of Ado-Rib/mg DNA from the liver, the kidney and the spleen of rats, respectively (Table 1). They also reported the content of Ado-Rib-Rib (derived from branch point, Figure 2) as $0.8-1.6 \%$ of total PAR [76]. Jacobson et al. reported PAR level as 12 pmol Ado-Rib $/ 10^{8}$ normal human diploid fibroblasts (CF-3) and it increased to $200 \mathrm{pmol} / 10^{8}$ cells after UV irradiation [77]. They also measured PAR level in SV40-transformed Balb $/ 3$ T3 fibroblasts and reported as 0.09 or 0.14 pmol Ado-Rib/10 cells and it increased by hyperthermia at $43^{\circ} \mathrm{C}$ up to $5.25 \mathrm{pmol} / 10^{6}$ cells after $8 \mathrm{~h}$ [78] (Table 1). A review on various methods for biochemical study of PAR metabolism in vitro and in vivo was published in 1995 [79]. Malanga et al. using polyacrylamide gel electrophoresis (PAGE), silver staining and computer-aided scanning densitometry reported PAR level in human keratinocyte cell line (HaKaT) as $0.554 \mathrm{pmol} / 10^{6}$ cells $(6.65 \mathrm{pmol} / 1.2 \times$ $10^{7}$ cells) and it increased to $11.1 \mathrm{pmol} / 10^{6}$ cells $\left(133 \mathrm{pmol} / 1.2 \times 10^{7}\right.$ cells $)$ after MNNG treatment [80] 
(Table 1). The interesting point is that although the total amount of PAR (the sum of ADP-ribose residues) is 20 times larger in the MNNG-treated cells, the chain length distribution pattern of PAR in the control (intact) cells seems not so different from that of MNNG-treated cells.

In 2008, Kinders et al. reported a sandwich ELISA of protein-bound PAR in tumor biopsies of human melanoma xenografts in mice after in vivo administration of PARP inhibitors (Table 1). This was a Phase 0 clinical trial of pharmacodynamic assay of PAR, leading to the current human clinical Phase 1 and 2 studies of PARP inhibitor in combination with anti-cancer drugs [81]. To invent a non-invasive procedure to monitor the effects of PARP inhibitor as a surrogate marker of the tumor in the body, Ji et al. using the above method of Kinders et al., reported PAR level in human peripheral blood mononuclear cells (PBMC) as $0.024 \mathrm{pmol} / 10^{6} \mathrm{PBMC}$ (13.17 ag/cell) from healthy volunteer and $0.028 \mathrm{pmol} / 10^{6} \mathrm{PBMC}(14.92 \mathrm{ag} / \mathrm{cell})$ from patients with cancer. The intra- and inter-individual variation over 3 weeks in healthy volunteers was $0.008-0.198 \mathrm{pmol} / 10^{6} \mathrm{PBMC}$ (4.4-107.3 ag/cell) [46] (Table 1). The reason there was relatively big variation of intra- and inter-individual variation of PAR levels in PBMC, as compared to the later report by another researcher group [72] (Table 1), is not known at present. However, it might be necessary to compare precisely the conditions of preparation of PBMC samples before analyzing the actual PAR levels.

In 2013, Martello et al. reported PAR levels using a modern technique of stable isotope dilution liquid chromatography-tandem mass spectrometry (LC-MS/MS) system (Table 1). They synthesized ${ }^{13} \mathrm{C}_{1}^{15} \mathrm{~N}$-labeled PAR from ${ }^{13} \mathrm{C}_{,}^{15} \mathrm{~N}$-labeled $\mathrm{NAD}^{+}$and added to the sample as tracer for estimating the recovery of PAR during purification. They reported PAR levels as $0.03 \mathrm{pmol} / 10^{6} \mathrm{PBMC}$ and $0.05-0.1 \mathrm{pmol} / 10^{6} \mathrm{HeLa}$ cells. It is interesting that although there was little variation of basal PAR levels in PBMC from different donors, there was considerable interdonor variation of increased PAR levels after $\mathrm{H}_{2} \mathrm{O}_{2}$ stress. They also reported the PAR levels of mouse tissues as $21.5 \pm 11.4,10.3 \pm 3.4$, $7.5 \pm 1.7,6.2 \pm 2.3,5.9 \pm 1.5,4.6 \pm 1.6$ and $2.7 \pm 1.0 \mathrm{pmol} / \mathrm{mg}$ DNA for the heart, the kidney, the liver, the thymus, the testis, the spleen, and the lung, respectively [72].

Up until now, for measurement of physiological low level of PAR, the importance of the sensitivity and the specificity have been greatly emphasized. However there have been less attention on the artificial synthesis or degradation of PAR during the extraction procedures. We recently reported a sandwich ELISA system to detect protein free PAR level with special attention to use TCA and not ordinary cell lysis buffer to extract PAR to avoid any artificial synthesis or degradation of PAR before ELISA. We used two kinds of antibodies against PAR, namely monoclonal antibody 10H [82] as catching antibody and rabbit polyclonal antibody against PAR, as was already reported [70]. To remove cross reacting or inhibiting materials as much as possible, in addition to DNase I and RNase A, nuclease P1 was used to digest oligonucleotides to $5^{\prime}$-mononucleotides. We also digested proteins in the sample to avoid any interference of the assay. In addition, to ensure the recovery of PAR, we did not use any columns such as DHB-Sepharose. With this method it became possible to measure the basal PAR level using $10^{6}$ cells. The PAR levels were $0.039 \mathrm{pmol} / 10^{6} \mathrm{HeLa}$ cells $(20.8 \mathrm{ag} / \mathrm{cell}), 0.038 \mathrm{pmol} / 10^{6} \mathrm{HEK} 293 \mathrm{~T}$ cells $(20.5 \mathrm{ag} / \mathrm{cell})$, and $0.002 \mathrm{pmol} / 10^{6}$ HepG2 cells (1.0 ag/cell). The PAR level of HeLa cells increased 160 times to $6.39 \mathrm{pmol} / 10^{6} \mathrm{HeLa}$ cells (3460 ag/cell) after MNNG treatment [73]. The amount of PAR in HeLa cells is consistent with the value reported by Martello et al. [72] (Table 1). If the chain length distribution pattern of PAR did not change significantly in physiological condition, it is understandable that both ELISA system and LC-MS/MS system give similar results on the total amount of PAR. Yamashita et al. in the same research group reported PAR level in HeLa cells as $0.025 \mathrm{pmol} / 10^{6}$ cells $(13.3 \mathrm{ag} / \mathrm{cell})$ and $0.074 \mathrm{pmol} / 10^{6} \mathrm{cells}(39.3 \mathrm{ag} / \mathrm{cell})$ at $37^{\circ} \mathrm{C}$; $0.023 \mathrm{pmol} / 10^{6}$ cells $(12.5 \mathrm{ag} /$ cell $)$ at $33.5^{\circ} \mathrm{C} ; 0.085 \mathrm{pmol} / 10^{6}$ cells $(45.4 \mathrm{ag} /$ cell $)$ and $0.155 \mathrm{pmol} / 10^{6}$ cells (82.9 ag/cell) at $40.5^{\circ} \mathrm{C}$. The PAR level in CHO-K1 cells was $0.063 \mathrm{pmol} / 10^{6} \mathrm{cells}(33.7 \mathrm{ag} / \mathrm{cell})$ at $37^{\circ} \mathrm{C}$ and $0.128 \mathrm{pmol} / 10^{6}$ cells $(68.2 \mathrm{ag} / \mathrm{cell})$ at $40.5^{\circ} \mathrm{C}$ (Table 1$)$. With western blot analysis, $\gamma \mathrm{H} 2 \mathrm{AX}$ protein band was detected when HeLa cells or CHO-K1 cells were cultured at $40.5{ }^{\circ} \mathrm{C}$ and it further increased in the presence of $7 \mathrm{mM} 3 \mathrm{AB}$, a PARP inhibitor. Immunocytochemistry also showed similar results [83]. These results suggested the occurrence of double strand DNA breaks occurring at relatively mild shifted-up temperatures such as $40.5^{\circ} \mathrm{C}$, during which we might sometimes experience a microbial infection in daily life. 
Table 1. In vivo level of PAR assayed by various methods.

\begin{tabular}{|c|c|c|c|c|c|c|c|c|c|}
\hline $\begin{array}{l}\text { Name of } \\
\text { Methods }\end{array}$ & Target & Reagents & Tissues or Cells & Fixation & Extraction, Purification & Sensitivity * & Level of PAR * & $\begin{array}{c}\text { Comments by } \\
\text { Authors }\end{array}$ & References \\
\hline $\begin{array}{c}\text { Chemical } \\
\text { analysis }\end{array}$ & Histone $\mathrm{F} 1$ & & Rat liver nuclei & $\begin{array}{l}\text { Histone } \mathrm{F} 1 \text { extracted with } 5 \% \\
\mathrm{HClO}_{4} \text { and precipitated with } \\
20 \% \text { TCA }\end{array}$ & $\begin{array}{l}\text { DEAE-cellulose column } \\
\text { chromatography to separate } \\
\text { from non-histone proteins }\end{array}$ & & $\begin{array}{l}0.89-1.73 \mathrm{nmol} / \mathrm{mg} \mathrm{F} 1 \\
\text { histone protein }\end{array}$ & & $\begin{array}{l}\text { Smith and } \\
\text { Stocken (1973) } \\
{[66]}\end{array}$ \\
\hline Isotope dilution & Ado(P)-Rib-P & $\begin{array}{l}{\left[{ }^{3} \mathrm{H}\right] \mathrm{PAR} \text { as indicator, }} \\
\text { prepared using } \\
\text { sonicated Erlich } \\
\text { carcinoma cell lysate as } \\
\text { enzyme source }\end{array}$ & $\begin{array}{l}\text { Rat liver (adult and } \\
\text { neonatal), Zajdela } \\
\text { hepatoma }\end{array}$ & Freeze-clamped (rat liver) & $\begin{array}{c}\text { Homogenized in } 0.25 \mathrm{~N} \mathrm{KOH}, \\
\text { sonicated, } 1 \mathrm{M} \mathrm{N} \mathrm{NH}_{2} \mathrm{OH} \text {; venom } \\
\mathrm{PDE} ; \text { anion exchange column } \\
\text { chromatography; paper } \\
\text { chromatography; phosphatase; } \\
\text { paper chromatography }\end{array}$ & & $\begin{array}{c}5.59 \text { (adult), } 6.32 \text { (neonatal), } \\
1.24 \text { (hepatoma) nmol/mg } \\
\text { DNA }\end{array}$ & & $\begin{array}{c}\text { Stone et al. (1976) } \\
\text { [67] }\end{array}$ \\
\hline RIA & PAR & $\begin{array}{l}{\left[{ }^{14} \mathrm{C}\right] \mathrm{PAR}, \text { polyclonal }} \\
\text { antibody against PAR }\end{array}$ & HeLa cells & $\begin{array}{c}0.1 \mathrm{~N} \mathrm{NaOH}, 2 \mathrm{~h}, 37^{\circ} \mathrm{C} ; 4^{\circ} \mathrm{C} \\
\text { overnight }\end{array}$ & $\begin{array}{l}\text { DNase I, micrococcal nuclease; } \\
\text { Pronase; phenol extraction }\end{array}$ & & $\begin{array}{l}3.7 \mathrm{pmol} / 10^{6} \mathrm{HeLa} \text { cells; } \\
\text { small peak of PAR at S phase } \\
\text { and large peak at G2 phase }\end{array}$ & & $\begin{array}{l}\text { Kidwell and } \\
\text { Mage (1976) [71] }\end{array}$ \\
\hline RIA & PAR & $\begin{array}{l}{\left[{ }^{14} \mathrm{C}\right] \mathrm{PAR} \text {, polyclonal }} \\
\text { antibody against PAR }\end{array}$ & Calf tissues & Frozen after slaughterhouse & $\begin{array}{l}\text { Homogenized to isolate nuclei } \\
\text { and ethanol precipitation; or } \\
\text { homogenized in } 5 \% \text { TCA } \\
\text { without isolating nuclei; Pronase; } \\
\text { phenol extraction; DNase I, } \\
\text { RNase, nuclease P1; Pronase; } \\
\text { phenol extraction; } \\
\text { hydroxyapatite column } \\
\text { chromatography }\end{array}$ & $\begin{array}{c}10 \text { pmol of } \\
\text { PAR }\end{array}$ & $\begin{array}{c}37 \mathrm{pmol} / \mathrm{mg} \text { DNA or } 740 \\
\mathrm{pmol} / \mathrm{g} \text { calf thymus }\end{array}$ & $\begin{array}{c}\text { Chain length } \\
\text { distribution shown } \\
\text { with hydroxyapatite } \\
\text { column } \\
\text { chromatography }\end{array}$ & $\begin{array}{l}\text { Sakura et al. } \\
\text { (1977) [74] }\end{array}$ \\
\hline $\begin{array}{l}\text { Fluorescence } \\
\text { method }\end{array}$ & $\begin{array}{l}\text { Etheno } \\
\text { Ado-Rib }\end{array}$ & $\begin{array}{l}\text { Fluorescent labeling of } \\
\text { Ado-Rib }\end{array}$ & $\begin{array}{l}\text { SV40-transformed } \\
\text { 3T3 cells }\end{array}$ & $20 \%$ TCA & $\begin{array}{l}0.1 \mathrm{M} \text { potassium phosphate }(\mathrm{pH} \\
5 \text { ) in } 6 \mathrm{M} \text { guanidine } \\
\text { hydrochloride, sonication; } \\
\text { dihydroxyboryl-Sepharose } \\
\text { column chromatography; } \\
\text { alkaline phosphatase and venom } \\
\mathrm{PDE} \text {; chloroacetaldehyde; HPLC }\end{array}$ & $\begin{array}{l}5 \mathrm{pmol} \text { of } \\
\text { Ado-Rib }\end{array}$ & $\begin{array}{c}0.05 \mathrm{pmol} / 10^{6} \mathrm{SV} 40 \\
\text { virus-transformed } 3 \mathrm{~T} 3 \text { cells, } \\
\text { increased to } \\
7.50 \text { pmol } / 10^{6} \text { cells after } 20 \\
\text { min of MNNG }\end{array}$ & & $\begin{array}{l}\text { Juarez-Salinas et } \\
\text { al. (1979) [75] }\end{array}$ \\
\hline RIA: Method A & Ado(P)-Rib-P & $\begin{array}{c}{\left[^{3} \mathrm{H}\right] \mathrm{PAR} \text { as tracer }} \\
\text { prepared using Ehrlich } \\
\text { carcinoma cell nuclei, } \\
{\left[{ }^{3} \mathrm{H} \text { Hddod(P)-Rib--; }\right.} \\
\text { antibody against } \\
\text { Ado(P)-Rib-P }\end{array}$ & Rat liver (adult) & Freeze-clamped and frozen & $\begin{array}{c}\text { Homogenized in } 20 \% \mathrm{TCA} ; \\
\text { dissolved in } 6 \mathrm{M} \text { guanidine } \\
\text { hydrochloride and morpholine } \\
\text { buffer; } 0.3 \mathrm{M} \mathrm{NaOH}, 1 \mathrm{~h}, 56^{\circ} \mathrm{C} ; \\
\text { boronate column } \\
\text { chromatography; venom PDE; } \\
\text { HPLC } \\
\end{array}$ & $\begin{array}{c}1 \text { pmol } \\
\text { Ado(P)-Rib-P }\end{array}$ & $\begin{array}{l}88.6 \pm 20.7 \text { and } 72.6 \mathrm{pmol} / \mathrm{g} \\
\text { tissue }\end{array}$ & & $\begin{array}{l}\text { Wielkens et al. } \\
\text { (1981) [69] }\end{array}$ \\
\hline RIA: Method B & Ado(P)-Rib-P & Same as above & Same as above & Same as above & $\begin{array}{l}\text { Homogenized in } 20 \% \text { TCA; } \\
\text { dissolved in cold water; } 0.33 \mathrm{M} \\
\text { NaOH, } 3 \mathrm{~h}, 56^{\circ} \mathrm{C} \text {; alkaline } \\
\text { phosphatase; proteinase K; heat } \\
\text { inactivation; venom PDE; } 5 \% \\
\text { TCA; anion exchange column } \\
\text { chromatography, HPLC }\end{array}$ & $\begin{array}{c}1 \text { pmol } \\
\text { Ado(P)-Rib-P }\end{array}$ & $\begin{array}{c}89.0 \pm 10.7 \text { and } 128.1 \pm 7.3 \\
\mathrm{pmol} / \mathrm{g} \text { tissue }\end{array}$ & & $\begin{array}{l}\text { Wielkens et al. } \\
\text { (1981) [69] }\end{array}$ \\
\hline
\end{tabular}


Table 1. Cont.

\begin{tabular}{|c|c|c|c|c|c|c|c|c|c|}
\hline $\begin{array}{l}\text { Name of } \\
\text { Methods }\end{array}$ & Target & Reagents & Tissues or Cells & Fixation & Extraction, Purification & Sensitivity * & Level of PAR * & $\begin{array}{l}\text { Comments by } \\
\text { Authors }\end{array}$ & References \\
\hline RIA & Ado(P)-Rib-P & $\begin{array}{l}\text { RIA Method A } \\
\text { (Wielkens et al. 1981) } \\
\text { [69] }\end{array}$ & $\begin{array}{l}\text { Rat liver (adult and } \\
\text { neonatal) and } \\
\text { hepatoma }\end{array}$ & $\begin{array}{l}\text { Freeze-clamped and frozen (rat } \\
\text { liver) or washed and frozen in } \\
\text { liquid nitrogen (hepatoma cells) }\end{array}$ & $\begin{array}{l}\text { RIA Method A (Wielkens et al., } \\
\text { 1981) [69] }\end{array}$ & $\begin{array}{c}1 \text { pmol } \\
\text { Ado(P)-Rib-P }\end{array}$ & $\begin{array}{c}32 \pm 9,10 \pm 2,39 \pm 5 \\
\text { pmol } / \mathrm{mg} \text { DNA of neonatal } \\
\text { (1 day), neonatal (17 days) } \\
\text { and adult ( }>150 \text { days) rat } \\
\text { liver, respectively. } 61 \pm 11, \\
25 \pm 3 \text { and } 60 \pm 17 \mathrm{pmol} / \mathrm{mg} \\
\text { DNA for AH130, AH } 7974 \\
\text { and Reuber } \mathrm{H} 35 \text { hepatomas, } \\
\text { respectively }\end{array}$ & & $\begin{array}{l}\text { Bredehorst et al } \\
\quad(1981)[68]\end{array}$ \\
\hline $\begin{array}{l}\text { Fluorescence } \\
\text { method }\end{array}$ & $\begin{array}{l}\text { Etheno } \\
\text { Ado-Rib and } \\
\text { etheno } \\
\text { Ado-Rib-Rib }\end{array}$ & $\begin{array}{c}\text { Fluorescent labeling of } \\
\text { specific degradation } \\
\text { product, Ado-Rib and } \\
\text { Ado-Rib-Rib }\end{array}$ & $\begin{array}{l}\text { Rat liver, kidney } \\
\text { and spleen }\end{array}$ & $20 \%$ TCA & Juarez-Salinas et al. (1979) [75] & & $\begin{array}{l}\text { 14, } 18 \text {, and } 8.0 \mathrm{pmol} \text { of } \\
\text { Ado-Rib/mg DNA of liver, } \\
\text { kidney and spleen of rat, } \\
\text { respectively; Ado-Rib-Rib } \\
\text { constituted } 0.8-1.6 \% \text { of total } \\
\text { PAR }\end{array}$ & & $\begin{array}{l}\text { Juarez-Salinas et } \\
\text { al. (1982) [76] }\end{array}$ \\
\hline $\begin{array}{l}\text { Fluorescence } \\
\text { method }\end{array}$ & $\begin{array}{l}\text { Etheno } \\
\text { Ado-Rib }\end{array}$ & $\begin{array}{l}\text { Fluorescent labeling of } \\
\text { specific degradation } \\
\text { product, Ado-Rib }\end{array}$ & $\begin{array}{l}\text { Normal human } \\
\text { diploid fibroblasts } \\
\text { (CF-3) }\end{array}$ & $20 \%$ TCA & $\begin{array}{l}\text { MOPS/KOH (pH 8.8) in 6 M } \\
\text { guanidine hydrochloride, } \\
\text { sonication; dihydroxyboryl } \\
\text { BioRex 70 resin; alkaline } \\
\text { phosphatase and venom PDE; } \\
\text { fluorescent etheno derivatization; } \\
\text { dihydroxyboronate column } \\
\text { chromatography; HPLC }\end{array}$ & & $\begin{array}{l}0.12 \mathrm{pmol} \text { Ado-Rib } / 10^{6} \text { cells; } \\
\text { increased to } \\
2.0 \mathrm{pmol} / 10^{6} \text { cells after UV }\end{array}$ & & $\begin{array}{l}\text { Jacobson et al. } \\
\text { (1983) [77] }\end{array}$ \\
\hline $\begin{array}{l}\text { Fluorescence } \\
\text { method }\end{array}$ & $\begin{array}{l}\text { Etheno } \\
\text { Ado-Rib }\end{array}$ & $\begin{array}{l}\text { Fluorescent labeling of } \\
\text { Ado-Rib }\end{array}$ & $\begin{array}{l}\text { SV40-transformed } \\
\text { Balb/3T3 } \\
\text { fibroblasts }\end{array}$ & $20 \%$ TCA & Jacobson et al. (1983) [77] & & $\begin{array}{c}0.09 \text { or } 0.14 \mathrm{pmol} \\
\text { Ado-Rib } / 10^{6} \text { cells: increased } \\
\text { by hyperthermia at } 43^{\circ} \mathrm{C} \text { up } \\
\text { to } 5.25 \text { pmol } / 10^{6} \text { cells after } 8 \\
\mathrm{~h}\end{array}$ & $\begin{array}{c}\text { No significant DNA } \\
\text { strand breaks upon } \\
\text { alkaline sucrose } \\
\text { gradient } \\
\text { centrifugation }\end{array}$ & $\begin{array}{l}\text { Juarez-Salinas et } \\
\text { al. (1984) [78] }\end{array}$ \\
\hline $\begin{array}{l}\text { PAGE, silver } \\
\text { staining and } \\
\text { computer-aided } \\
\text { scanning } \\
\text { densitometry }\end{array}$ & PAR & PAR standard & $\begin{array}{c}\text { Human } \\
\text { keratinocyte cell } \\
\text { line (HaKaT) }\end{array}$ & $20 \%$ TCA & $\begin{array}{c}\text { Proteinase K (DNase I, RNase); } 1 \\
\text { M KOH, } 37^{\circ} \mathrm{C} 2 \mathrm{~h} ; \\
\text { dihydroxyboronate column } \\
\text { chromatography; } 20 \% \text { PAGE; } \\
\text { silver staining; scanned with } \\
\text { computing densitometer } \\
\text { (ImageQuant } 3.15 \text { software) }\end{array}$ & & $\begin{array}{l}0.55 \mathrm{pmol} / 10^{6} \text { cells; } \mathrm{MNNG} \\
\text { treatment increased to } \\
11.1 \mathrm{pmol} / 10^{6} \text { cells }\end{array}$ & $\begin{array}{l}\text { Chain length } \\
\text { distribution shown } \\
\text { with PAGE }\end{array}$ & $\begin{array}{l}\text { Malanga et al. } \\
\text { (1995) [80] }\end{array}$ \\
\hline $\begin{array}{l}\text { Sandwich } \\
\text { ELISA }\end{array}$ & $\begin{array}{l}\text { Protein-bound } \\
\text { PAR }\end{array}$ & $\begin{array}{l}\text { PAR standard; mouse } \\
\text { monoclonal }(10 \mathrm{H}) \text { and } \\
\text { rabbit polyclonal } \\
\text { antibody against PAR }\end{array}$ & $\begin{array}{c}\text { Xenograft tumors of } \\
\text { human melanoma } \\
\text { cell lines (A375 and } \\
\text { Colo829) }\end{array}$ & Fresh frozen & $\begin{array}{c}\text { Sonicated in lysis buffer } \\
\text { (Biosource) with protease } \\
\text { inhibitors; } 1 \% \text { SDS; boiled } 5 \text { min; } \\
\text { supernatant }\end{array}$ & & $\begin{array}{c}5584 \text { units PAR (large } \\
\text { tumors); } 4146 \text { units PAR } \\
\text { (small tumors) [All units are } \\
\text { pg PAR/mL per } 100 \mathrm{mg} \\
\text { protein]; Higher amount of } \\
\text { protein and DNA caused } \\
\text { interference }\end{array}$ & $\begin{array}{l}\text { Protein and DNA } \\
\text { were not digested. } \\
\text { Protein concentration } \\
\text { should be diluted to } \\
0.1-1 \mathrm{mg} / \mathrm{mL} \text { before } \\
\text { assay. Effect of dose } \\
\text { of PARP inhibitor and } \\
\text { time course of PAR } \\
\text { levels in xenograft } \\
\text { were presented }\end{array}$ & $\begin{array}{l}\text { Kinders et al. } \\
(2008)[81]\end{array}$ \\
\hline
\end{tabular}


Table 1. Cont.

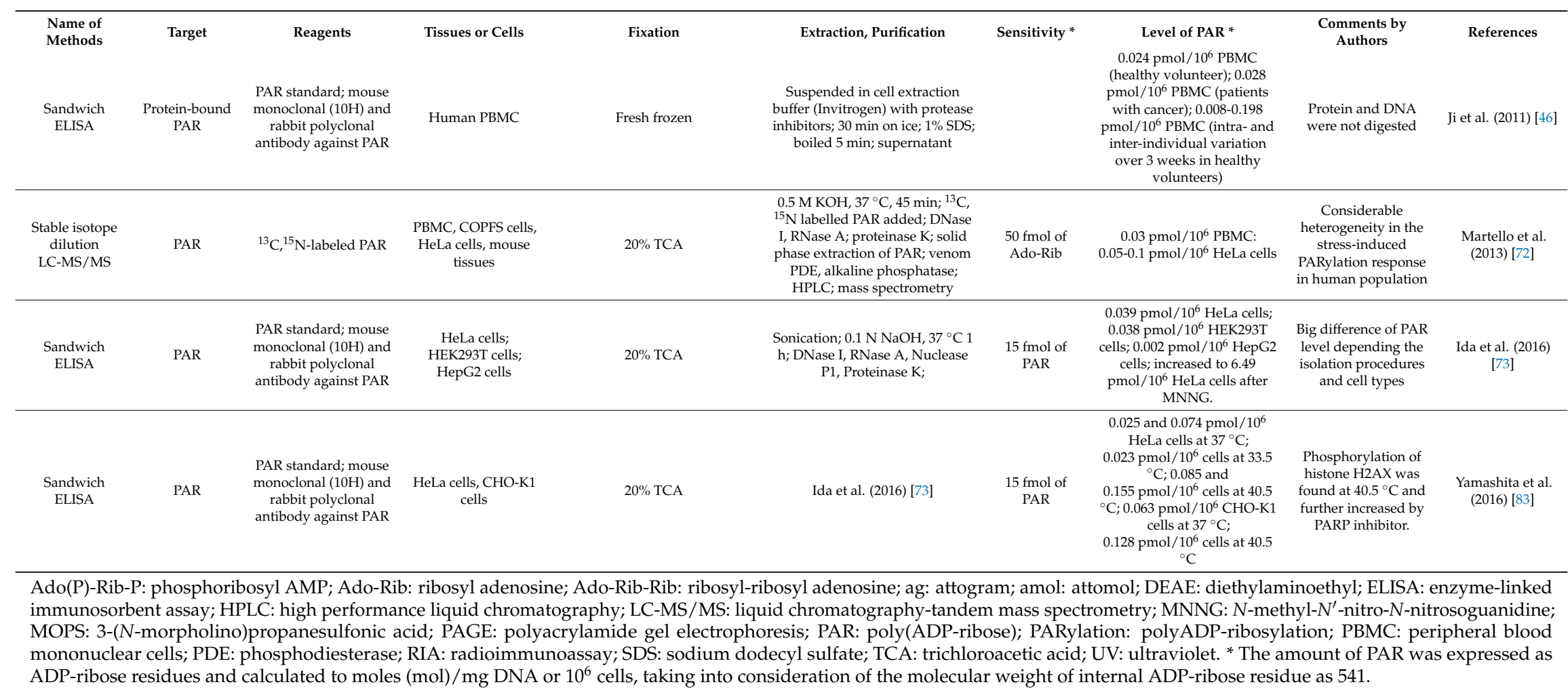


As described in the "Proposed functions of polyADP-ribosylation" section of this review, analysis of the amino acid modification sites of the acceptor proteins by polyADP-ribosylation are important, since they might directly modify the function of the acceptor proteins and also change the protein-protein interaction. For this purpose Chapman et al. hydrolyzed polyADP-ribosylated PARP1 with snake venom phosphodiesterase, and determined phospho-ribosylated amino acid residues using liquid chromatography-tandem mass spectrometry [84]. The quantification of the PAR attached to each acceptor amino acids will be expected direction in the future research. Since the structure of PAR with long chain length with many branches $[52,53]$ is not studied well, it will be necessary not only to measure the amount of PAR, but also to analyze the role of the big PAR as a scaffold to support essential cellular functions. In this context, analysis of the proteomic approach to search protein motifs, which bind non-covalently to PAR, will give valuable information $[56,85,86]$. The information is important for analyzing the function of PAR in molecular levels. At the present time, we think our sandwich ELISA system will be useful in every research laboratory without expensive instrumentation, and is cost-effective. The catching monoclonal antibody (10H; anti poly(ADP-ribose) IgG3 kappa producing), which is necessary to coat the wells could be easily prepared by culturing $10 \mathrm{H}$ hybridoma cells [82], which is available from The RIKEN BioResource Research Center (BRC), a non-profit institution funded by the Japanese Government, under the code of (Cell No. RCB0705) (http:/ / cell.brc.riken.jp/en/creditpay).

In addition it might be mentioned here that monoADP-ribosylation reaction is as important as polyADP-ribosylation in biological reaction. However, there is no suitable method to quantify the number of ADP-ribose molecules attached to each amino acids of the acceptor proteins. It is expected to develop such methods by applying recent techniques including mass spectrometry.

\subsection{Prospect: In Vivo PAR Level to Understand More Biological Functions and Its Application for Clinic}

PARP1 has been known to function in base excision repair (BER). When a single-strand break of DNA occurs, PARP1 immediately binds to the sites of DNA breaks and is activated to synthesize PAR attached to PARP1 itself (automodification), serving as a scaffold for recruiting BER enzymes. However, when PARP1 is inhibited by chemical inhibitor, single strand break persists and could make double strand break when replication fork passes through during DNA replication. These double strand breaks are usually repaired by homologous recombination controlled by $B R C A 1 / 2$ gene(s). Therefore BRCA1- and BRCA2-mutated human breast cancer cells are subjected to killing by PARP inhibitors. This idea and the data were presented by 2 important papers (synthetic lethality) $[87,88]$. Since various anticancer drugs target DNA to make strand breaks to kill cancer cells, inhibition of DNA repair system in cancer cells is utmost effective. For this reason, combination of PARP inhibitors to DNA damaging anticancer drugs have also been studied in Phase 1 and 2 clinical trials [89-92]. It is interesting that cisplatin resistant non-small cell lung carcinoma cells frequently show hyperactivation of PARP than original tumor cells and the elevated PAR levels could be more accurate marker than the expression levels of PARP protein to predict the susceptibility of the cancer cells to PARP inhibitors [93].

Besides cancer, treatment of neurodegenerative diseases including Alzheimer disease and Parkinson's disease becomes important in developed countries. When PAR is not degraded by mutation of degradation enzyme, PARG, neurodegenerative changes occurs in the brain and caused neurological symptoms in experimental animal model [26]. Also when the enzyme, TARG1, is mutated severe neurological symptoms appeared in the patient [12]. In addition, other diseases such as inflammation and immunological diseases are also considered to be possible targets of PARP inhibitors [94].

\section{Conclusions}

Since various biological functions have been proposed as described in the first part of this review, if we know more about quantitative view such as that on PAR level, we will be much closer to inventing effective methods to control or prevent diseases. Precise genomic information in addition to $B R C A$ 
mutation might be required for classification of heterogeneous diseases to be treated. The important thing is that we will encourage more intimate information exchanges between bench and bedside.

Author Contributions: M.M. conceived the contents of this review; M.M., C.I., S.Y., Y.K., T.E., N.O., T.S. and M.Ta. had performed the cited experiments, which motivated to write this review; M.M., K.K., M.Ts. and M.Ta. collected the references and analyzed the data of sample preparation of the cited references on the in vivo level of PAR; M.M. wrote the paper.

Funding: The funding from the Ministry of Education, Culture, Sports, Science and Technology, from the Ministry of Health, Labour and Welfare, Japan, and from Nagahama Institute of Bio-Science and Technology, Japan, are greatly acknowledged.

Acknowledgments: We thank Kazuo Kamemura of Nagahama Institute of Bio-Science and Technology for critical reading of the manuscript. We also thank many collaborative researchers for support of our work.

Conflicts of Interest: The authors declare no conflict of interest.

\section{References}

1. Sugimura, T. Poly(adenosine diphosphate ribose). Prog. Nucleic Acid Res. Mol. Biol. 1973, 13, $127-151$. [PubMed]

2. Miwa, M.; Masutani, M. PolyADP-ribosylation and cancer. Cancer Sci. 2007, 98, 1528-1535. [CrossRef] [PubMed]

3. Hottiger, M.O.; Hassa, P.O.; Lüscher, B.; Schüler, H.; Koch-Nolte, F. Toward a unified nomenclature for mammalian ADP-ribosyltransferases. Trends Biochem. Sci. 2010, 35, 208-219. [CrossRef] [PubMed]

4. Chambon, P.; Weill, J.; Doly, J.; Strosser, M.; Mandel, P. On the formation of a novel adenylic compound by enzymatic extracts of liver nuclei. Biochem. Biophys Res. Commun. 1966, 25, 634-643. [CrossRef]

5. Sugimura, T.; Fujimura, S.; Hasegawa, S.; Kawamura, Y. Polymerization of the adenosine $5^{\prime}$-diphosphate ribose moiety of NAD by rat liver nuclear enzyme. Biochim. Biophys. Acta 1967, 138, 438-441. [CrossRef]

6. Nishizuka, Y.; Ueda, K.; Nakazawa, K.; Hayaishi, O. Studies on the polymer of adenosine diphosphate ribose. I. Enzymic formation from nicotinamide adenine dinuclotide in mammalian nuclei. J. Biol. Chem. 1967, 242, 3164-3171. [PubMed]

7. Morrison, A.R.; Moss, J.; Stevens, L.A.; Evans, J.E.; Farrell, C.; Merithew, E.; Lambright, D.G.; Greiner, D.L.; Mordes, J.P.; Rossini, A.A.; et al. ART2, a T cell surface mono-ADP-ribosyltransferase, generates extracellular poly(ADP-ribose). J. Biol. Chem. 2006, 281, 33363-33372. [CrossRef] [PubMed]

8. Miwa, M.; Sugimura, T. Splitting of the ribose-ribose linkage of poly(adenosine diphosphate-robose) by a calf thymus extract. J. Biol. Chem. 1971, 246, 6362-6364. [PubMed]

9. Ueda, K.; Oka, J.; Narumiya, S.; Miyakawa, N.; Hayaishi, O. Poly ADP-ribose glycohydrolase from rat liver nuclei, a novel enzyme degrading the polymer. Biochem. Biophys Res. Commun. 1972, 46, 516-523. [CrossRef]

10. Oka, S.; Kato, J.; Moss, J. Identification and characterization of a mammalian 39-kDa poly(ADP-ribose) glycohydrolase. J. Biol. Chem. 2006, 281, 705-713. [CrossRef] [PubMed]

11. Oka, J.; Ueda, K.; Hayaishi, O.; Komura, H.; Nakanishi, K. ADP-ribosyl protein lyase. Purification, properties, and identification of the product. J. Biol. Chem. 1984, 259, 986-995. [PubMed]

12. Sharifi, R.; Morra, R.; Appel, C.D.; Tallis, M.; Chioza, B.; Jankevicius, G.; Simpson, M.A.; Matic, I.; Ozkan, E.; Golia, B.; et al. Deficiency of terminal ADP-ribose protein glycohydrolase TARG1/C6orf130 in neurodegenerative disease. EMBO J. 2013, 32, 1225-1237. [CrossRef] [PubMed]

13. Rosenthal, F.; Feijs, K.L.; Frugier, E.; Bonalli, M.; Forst, A.H.; Imhof, R.; Winkler, H.C.; Fischer, D.; Caflisch, A.; Hassa, P.O.; et al. Macrodomain-containing proteins are new mono-ADP-ribosylhydrolases. Nat. Struct. Mol. Biol. 2013, 20, 502-507. [CrossRef] [PubMed]

14. Jankevicius, G.; Hassler, M.; Golia, B.; Rybin, V.; Zacharias, M.; Timinszky, G.; Ladurner, A.G. A family of macrodomain proteins reverses cellular mono-ADP-ribosylation. Nat. Struct. Mol. Biol. 2013, 20, 508-514. [CrossRef] [PubMed]

15. Poltronieri, P.; Cerekovic, N. Roles of nicotinamide adenine dinucleotide (NAD $\left.{ }^{+}\right)$in biological systems. Challenges 2018, 9, 3. [CrossRef]

16. Ueda, K.; Hayaishi, O. ADP-ribosylation. Annu. Rev. Biochem. 1985, 54, 73-100. [CrossRef] [PubMed]

17. Althaus, F.R.; Richter, C. ADP-ribosylation of proteins. Enzymology and biological significance. Mol. Biol. Biochem. Biophys 1987, 37, 1-237. [PubMed] 
18. Schreiber, V.; Dantzer, F.; Ame, J.C.; de Murcia, G. Poly(ADP-ribose): Novel functions for an old molecule. Nat. Rev. Mol. Cell. Biol. 2006, 7, 517-528. [CrossRef] [PubMed]

19. Kraus, W.L. PARPs and ADP-Ribosylation: 50 Years ... and Counting. Mol. Cell 2015, 58, 902-910. [CrossRef] [PubMed]

20. Hottiger, M.O. Nuclear ADP-Ribosylation and Its Role in Chromatin Plasticity, Cell Differentiation, and Epigenetics. Annu. Rev. Biochem. 2015, 4, 227-263. [CrossRef] [PubMed]

21. Barkauskaite, E.; Jankevicius, G.; Ahel, I. Structures and Mechanisms of Enzymes Employed in the Synthesis and Degradation of PARP-Dependent Protein ADP-Ribosylation. Mol. Cell. 2015, 58, 935-946. [CrossRef] [PubMed]

22. Crawford, K.; Bonfiglio, J.J.; Mikoč, A.; Matic, I.; Ahel, I. Specificity of reversible ADP-ribosylation and regulation of cellular processes. Crit. Rev. Biochem. Mol. Biol. 2018, 53, 64-82. [CrossRef] [PubMed]

23. Wang, Z.Q.; Stingl, L.; Morrison, C.; Jantsch, M.; Los, M.; Schulze-Osthoff, K.; Wagner, E.F. PARP is important for genomic stability but dispensable in apoptosis. Genes Dev. 1997, 11, 2347-2358. [CrossRef] [PubMed]

24. De Murcia, J.M.; Niedergang, C.; Trucco, C.; Ricoul, M.; Dutrillaux, B.; Mark, M.; Oliver, F.J.; Masson, M.; Dierich, A.; LeMeur, M.; et al. Requirement of poly(ADP-ribose) polymerase in recovery from DNA damage in mice and in cells. Proc. Natl. Acad. Sci. USA 1997, 94, 7303-7307. [CrossRef] [PubMed]

25. Masutani, M.; Suzuki, H.; Kamada, N.; Watanabe, M.; Ueda, O.; Nozaki, T.; Jishage, K.; Watanabe, T.; Sugimoto, T.; Nakagama, H.; et al. Poly(ADP-ribose) polymerase gene disruption conferred mice resistant to streptozotocin-induced diabetes. Proc. Natl. Acad. Sci. USA 1999, 96, 2301-2304. [CrossRef] [PubMed]

26. Hanai, S.; Kanai, M.; Ohashi, S.; Okamoto, K.; Yamada, M.; Takahashi, H.; Miwa, M. Loss of poly(ADP-ribose) glycohydrolase causes progressive neurodegeneration in Drosophila melanogaster. Proc. Natl. Acad. Sci. USA 2004, 101, 82-86. [CrossRef] [PubMed]

27. Koh, D.W.; Lawler, A.M.; Poitras, M.F.; Sasaki, M.; Wattler, S.; Nehls, M.C.; Stöger, T.; Poirier, G.G.; Dawson, V.L.; Dawson, T.M. Failure to degrade poly(ADP-ribose) causes increased sensitivity to cytotoxicity and early embryonic lethality. Proc. Natl. Acad. Sci. USA 2004, 101, 17699-17704. [CrossRef] [PubMed]

28. Durkacz, B.W.; Omidiji, O.; Gray, D.A.; Shall, S. (ADP-ribose)n participates in DNA excision repair. Nature 1980, 283, 593-596. [CrossRef] [PubMed]

29. Smulson, M.; Stark, P.; Gazzoli, M.; Roberts, J. Release of template restriction for DNA synthesis by poly ADP(ribose) polymerase during the HeLa cell cycle. Exp. Cell Res. 1975, 90, 175-182. [CrossRef]

30. Simbulan-Rosenthal, C.M.; Rosenthal, D.S.; Smulson, M.E. Purification and characterization of poly(ADP-ribosyl)ated DNA replication/repair complexes. Methods Mol. Biol. 2011, 780, 165-190. [PubMed]

31. Tulin, A.; Spradling, A. Chromatin loosening by poly(ADP)-ribose polymerase (PARP) at Drosophila puff loci. Science 2003, 299, 560-562. [CrossRef] [PubMed]

32. Kraus, W.L. Transcriptional control by PARP-1: Chromatin modulation, enhancer-binding, coregulation, and insulation. Curr. Opin. Cell Biol. 2008, 20, 294-302. [CrossRef] [PubMed]

33. Aubin, R.J.; Fréchette, A.; de Murcia, G.; Mandel, P.; Lord, A.; Grondin, G.; Poirier, G.G. Correlation between endogenous nucleosomal hyper(ADP-ribosyl)ation of histone $\mathrm{H} 1$ and the induction of chromatin relaxation. EMBO J. 1983, 2, 1685-1693. [PubMed]

34. Realini, C.A.; Althaus, F.R. Histone shuttling by poly(ADP-ribosylation). J. Biol. Chem. 1992, 267, $18858-18865$. [PubMed]

35. Utakoji, T.; Hosoda, K.; Umezawa, K.; Sawamura, M.; Matsushima, T.; Miwa, M.; Sugimura, T. Induction of sister chromatid exchanges by nicotinamide in Chinese hamster lung fibroblasts and human lymphoblastoid cells. Biochem. Biophys. Res. Commun. 1979, 90, 1147-1152. [CrossRef]

36. Oikawa, A.; Tohda, H.; Kanai, M.; Miwa, M.; Sugimura, T. Inhibitors of poly(adenosine diphosphate ribose) polymerase induce sister chromatid exchanges. Biochem. Biophys. Res. Commun. 1980, 97, 1311-1316. [CrossRef]

37. Kanai, M.; Tong, W.M.; Sugihara, E.; Wang, Z.Q.; Fukasawa, K.; Miwa, M. Involvement of poly(ADP-Ribose) polymerase 1 and poly(ADP-Ribosyl)ation in regulation of centrosome function. Mol. Cell. Biol. 2003, 23, 2451-2462. [CrossRef] [PubMed]

38. Smith, S.; Giriat, I.; Schmitt, A.; de Lange, T. Tankyrase, a poly(ADP-ribose) polymerase at human telomeres. Science 1998, 282, 1484-1487. [CrossRef] [PubMed] 
39. Cohen-Armon, M.; Visochek, L.; Rozensal, D.; Kalal, A.; Geistrikh, I.; Klein, R.; Bendetz-Nezer, S.; Yao, Z.; Seger, R. DNA-independent PARP-1 activation by phosphorylated ERK2 increases Elk1 activity: A link to histone acetylation. Mol. Cell 2007, 25, 297-308. [CrossRef] [PubMed]

40. Kanai, M.; Hanashiro, K.; Kim, S.H.; Hanai, S.; Boulares, A.H.; Miwa, M.; Fukasawa, K. Inhibition of Crm1-p53 interaction and nuclear export of p53 by poly(ADP-ribosyl)ation. Nat. Cell Biol. 2007, 9, 1175-1183. [CrossRef] [PubMed]

41. Stilmann, M.; Hinz, M.; Arslan, S.C.; Zimmer, A.; Schreiber, V.; Scheidereit, C. A nuclear poly(ADP-ribose)-dependent signalosome confers DNA damage-induced IkappaB kinase activation. Mol. Cell 2009, 36, 365-378. [CrossRef] [PubMed]

42. Wang, Y.; Kim, N.S.; Haince, J.F.; Kang, H.C.; David, K.K.; Andrabi, S.A.; Poirier, G.G.; Dawson, V.L.; Dawson, T.M. Poly(ADP-ribose) (PAR) binding to apoptosis-inducing factor is critical for PAR polymerase-1-dependent cell death (parthanatos). Sci. Signal. 2011, 4, ra20. [CrossRef] [PubMed]

43. Masutani, M.; Fujimori, H. Poly(ADP-ribosyl)ation in carcinogenesis. Mol. Asp. Med. 2013, 34, $1202-1216$. [CrossRef] [PubMed]

44. Ji, Y.; Thomas, C.; Tulin, N.; Lodhi, N.; Boamah, E.; Kolenko, V.; Tulin, A.V. Charon Mediates Immune Deficiency-Driven PARP-1-Dependent Immune Responses in Drosophila. J. Immunol. 2016, 197, 2382-2389. [CrossRef] [PubMed]

45. Szabó, C.; Dawson, V.L. Role of poly(ADP-ribose) synthetase in inflammation and ischaemia-reperfusion. Trends Pharmacol. Sci. 1998, 19, 287-298. [CrossRef]

46. Ji, J.; Kinders, R.J.; Zhang, Y.; Rubinstein, L.; Kummar, S.; Parchment, R.E.; Tomaszewski, J.E.; Doroshow, J.H. Modeling pharmacodynamic response to the poly(ADP-Ribose) polymerase inhibitor ABT-888 in human peripheral blood mononuclear cells. PLoS ONE 2011, 6. [CrossRef] [PubMed]

47. Yoshihara, K.; Hashida, T.; Yoshihara, H.; Tanaka, Y.; Ohgushi, H. Enzyme-bound early product of purified poly(ADP-ribose) polymerase. Biochem. Biophys. Res. Commun. 1977, 78, 1281-1288. [CrossRef]

48. Ogata, N.; Ueda, K.; Hayaishi, O. ADP-ribosylation of histone H2B. Identification of glutamic acid residue 2 as the modification site. J. Biol. Chem. 1980, 255, 7610-7615. [PubMed]

49. Ogata, N.; Ueda, K.; Kagamiyama, H.; Hayaishi, O. ADP-ribosylation of histone H1. Identification of glutamic acid residues 2, 14, and the COOH-terminal lysine residue as modification sites. J. Biol. Chem. 1980, 255, 7616-7620. [PubMed]

50. Suzuki, H.; Quesada, P.; Farina, B.; Leone, E. In vitro poly(ADP-ribosyl)ation of seminal ribonuclease. J. Biol. Chem. 1986, 261, 6048-6055. [PubMed]

51. Wesierska-Gadek, J.; Schmid, G.; Cerni, C. ADP-ribosylation of wild-type p53 in vitro: Binding of p53 protein to specific p53 consensus sequence prevents its modification. Biochem. Biophys. Res. Commun. 1996, 224, 96-102. [CrossRef] [PubMed]

52. Miwa, M.; Saikawa, N.; Yamaizumi, Z.; Nishimura, S.; Sugimura, T. Structure of poly(adenosine diphosphate ribose): Identification of $2^{\prime}$-[ $1^{\prime \prime}$-ribosyl-2 ${ }^{\prime \prime}$-(or $\left.3^{\prime \prime}-\right)\left(1^{\prime \prime \prime}\right.$-ribosyl)]adenosine- $5^{\prime}, 5^{\prime \prime}, 5^{\prime \prime \prime}$-tris(phosphate) as a branch linkage. Proc. Natl. Acad. Sci. USA 1979, 76, 595-599. [CrossRef] [PubMed]

53. De Murcia, G.; Jongstra-Bilen, J.; Ittel, M.E.; Mandel, P.; Delain, E. Poly(ADP-ribose) polymerase auto-modification and interaction with DNA: Electron microscopic visualization. EMBO J. 1983, 2, 543-548. [PubMed]

54. Hayashi, K.; Tanaka, M.; Shimada, T.; Miwa, M.; Sugimura, T. Size and shape of poly(ADP-ribose): Examination by gel filtration, gel electrophoresis and electron microscopy. Biochem. Biophys. Res. Commun. 1983, 112, 102-107. [CrossRef]

55. Panzeter, P.L.; Realini, C.A.; Althaus, F.R. Noncovalent interactions of poly(adenosine diphosphate ribose) with histones. Biochemistry 1992, 31, 1379-1385. [CrossRef] [PubMed]

56. Malanga, M.; Althaus, F.R. Noncovalent protein interaction with poly(ADP-ribose). Methods Mol. Biol. 2011, 780, 67-82. [PubMed]

57. Li, M.; Yu, X. Function of BRCA1 in the DNA damage response is mediated by ADP-ribosylation. Cancer Cell 2013, 23, 693-704. [CrossRef] [PubMed]

58. Zaja, R.; Mikoč, A.; Barkauskaite, E.; Ahel, I. Molecular Insights into Poly(ADP-ribose) Recognition and Processing. Biomolecules 2012, 3, 1-17. [CrossRef] [PubMed]

59. Barkauskaite, E.; Jankevicius, G.; Ladurner, A.G.; Ahel, I.; Timinszky, G. The recognition and removal of cellular poly(ADP-ribose) signals. FEBS J. 2013, 280, 3491-3507. [CrossRef] [PubMed] 
60. Daniels, C.M.; Ong, S.E.; Leung, A.K. The Promise of Proteomics for the Study of ADP-Ribosylation. Mol. Cell 2015, 58, 911-924. [CrossRef] [PubMed]

61. Pleschke, J.M.; Kleczkowska, H.E.; Strohm, M.; Althaus, F.R. Poly(ADP-ribose) binds to specific domains in DNA damage checkpoint proteins. J. Biol. Chem. 2000, 275, 40974-40980. [CrossRef] [PubMed]

62. Miwa, M.; Ida, C.; Yamashita, S.; Tanaka, M.; Fujisawa, J. Poly(ADP-ribose): Structure, Physicochemical Properties and Quantification In Vivo, with Special Reference to Poly(ADP-ribose) Binding Protein Modules. Curr. Protein Pept. Sci. 2016, 17, 683-692. [CrossRef] [PubMed]

63. Doly, J.; Mandel, P. Mise en évidence de la biosynthèse in vivo d'un polymère composé, le polyadénosine diphosphoribose dans les noyaux de foie de poulet. C. R. Acad. Sci. 1967, 264, 2687-2690.

64. Ueda, K.; Omachi, A.; Kawaichi, M.; Hayaishi, O. Natural occurrence of poly(ADP-ribosyl) histones in rat liver. Proc. Natl. Acad. Sci. USA 1975, 72, 205-209. [CrossRef] [PubMed]

65. Kanai, Y.; Kawaminami, Y.; Miwa, M.; Matsushima, T.; Sugimura, T. Naturally-occurring antibodies to poly(ADP-ribose) in patients with systemic lupus erythematosus. Nature 1977, 265, 175-177. [CrossRef] [PubMed]

66. Smith, J.A.; Stocken, L.A. Identification of poly (ADP-ribose) covalently bound to histone F1 in vivo. Biochem. Biophys. Res. Commun. 1973, 54, 297-300. [CrossRef]

67. Stone, P.R.; Bredehorst, R.; Kittler, M.; Lengyel, H.; Hilz, H. Quantitative determination of poly(adenosine diphosphate ribose) in different hepatic tissues by an isotope dilution procedure. Hoppe Seylers $Z$. Physiol. Chem. 1976, 357, 51-56. [CrossRef] [PubMed]

68. Bredehorst, R.; Wielckens, K.; Adamietz, P.; Steinhagen-Thiessen, E.; Hilz, H. Mono(ADP-ribosyl)ation and poly(ADP-ribosyl)ation of proteins in developing liver and in hepatomas: Relation of conjugate subfractions to metabolic competence and proliferation rates. Eur. J. Biochem. 1981, 120, 267-274. [CrossRef] [PubMed]

69. Wielckens, K.; Bredehorst, R.; Adamietz, P.; Hilz, H. Protein-bound polymeric and monomeric ADP-ribose residues in hepatic tissues. Comparative analyses using a new procedure for the quantification of poly(ADP-ribose). Eur. J. Biochem. 1981, 117, 69-74. [CrossRef] [PubMed]

70. Kanai, Y.; Miwa, M.; Matsushima, T.; Sugimura, T. Anti-poly(ADP-ribose) antibody and its specificity. J. Biochem. 1975, 77, 5-6. [CrossRef]

71. Kidwell, W.R.; Mage, M.G. Changes in poly(adenosine diphosphate-ribose) and poly(adenosine diphosphate-ribose) polymerase in synchronous HeLa cells. Biochemistry 1976, 15, 1213-1217. [CrossRef] [PubMed]

72. Martello, R.; Mangerich, A.; Sass, S.; Dedon, P.C.; Bürkle, A. Quantification of cellular poly(ADP-ribosyl)ation by stable isotope dilution mass spectrometry reveals tissue- and drug-dependent stress response dynamics. ACS Chem. Biol. 2013, 8, 1567-1575. [CrossRef] [PubMed]

73. Ida, C.; Yamashita, S.; Tsukada, M.; Sato, T.; Eguchi, T.; Tanaka, M.; Ogata, S.; Fujii, T.; Nishi, Y.; Ikegami, S.; et al. An enzyme-linked immunosorbent assay-based system for determining the physiological level of poly(ADP-ribose) in cultured cells. Anal. Biochem. 2016, 494, 76-81. [CrossRef] [PubMed]

74. Sakura, H.; Miwa, M.; Tanaka, M.; Kanai, Y.; Shimada, T.; Matsushima, T.; Sugimura, T. Natural occurence of a biopolymer, poly (adenosine diphosphate ribose). Nucleic Acids Res. 1977, 4, 2903-2915. [CrossRef] [PubMed]

75. Juarez-Salinas, H.; Sims, J.L.; Jacobson, M.K. Poly(ADP-ribose) levels in carcinogen-treated cells. Nature 1979, 282, 740-741. [CrossRef] [PubMed]

76. Juarez-Salinas, H.; Levi, V.; Jacobson, E.L.; Jacobson, M.K. Poly(ADP-ribose) has a branched structure in vivo. J. Biol. Chem. 1982, 257, 607-609. [PubMed]

77. Jacobson, E.L.; Antol, K.M.; Juarez-Salinas, H.; Jacobson, M.K. Poly(ADP-ribose) metabolism in ultraviolet irradiated human fibroblasts. J. Biol. Chem. 1983, 258, 103-107. [PubMed]

78. Juarez-Salinas, H.; Duran-Torres, G.; Jacobson, M.K. Alteration of poly(ADP-ribose) metabolism by hyperthermia. Biochem. Biophys. Res. Commun. 1984, 122, 1381-1388. [CrossRef]

79. Shah, G.M.; Poirier, D.; Duchaine, C.G.; Desnoyers, S.; Lagueux, J.; Verreault, A.; Hoflack, J.C.; Kirkland, J.B.; Poirier, G.G. Methods for biochemical study of poly(ADP-ribose) metabolism in vitro and in vivo. Anal. Biochem. 1995, 227, 1-13. [CrossRef] [PubMed]

80. Malanga, M.; Bachmann, S.; Panzeter, P.L.; Zweifel, B.; Althaus, F.R. Poly(ADP-ribose) quantification at the femtomole level in mammalian cells. Anal. Biochem. 1995, 228, 245-251. [CrossRef] [PubMed] 
81. Kinders, R.J.; Hollingshead, M.; Khin, S.; Rubinstein, L.; Tomaszewski, J.E.; Doroshow, J.H.; Parchment, R.E. National Cancer Institute Phase 0 Clinical Trials Team. Preclinical modeling of a phase 0 clinical trial: Qualification of a pharmacodynamic assay of poly (ADP-ribose) polymerase in tumor biopsies of mouse xenografts. Clin. Cancer Res. 2008, 14, 6877-6885. [CrossRef] [PubMed]

82. Kawamitsu, H.; Hoshino, H.; Okada, H.; Miwa, M.; Momoi, H.; Sugimura, T. Monoclonal antibodies to poly(adenosine diphosphate ribose) recognize different structures. Biochemistry 1984, 23, 3771-3777. [CrossRef] [PubMed]

83. Yamashita, S.; Tanaka, M.; Sato, T.; Ida, C.; Ohta, N.; Hamada, T.; Uetsuki, T.; Nishi, Y.; Moss, J.; Miwa, M. Effect of mild temperature shift on poly(ADP-ribose) and $\gamma \mathrm{H} 2 \mathrm{AX}$ levels in cultured cells. Biochem. Biophys. Res. Commun. 2016, 476, 594-599. [CrossRef] [PubMed]

84. Chapman, J.D.; Gagné, J.P.; Poirier, G.G.; Goodlett, D.R. Mapping PARP-1 auto-ADP-ribosylation sites by liquid chromatography-tandem mass spectrometry. J. Proteome Res. 2013, 12, 1868-1880. [CrossRef] [PubMed]

85. Malanga, M.; Althaus, F.R. The role of poly(ADP-ribose) in the DNA damage signaling network. Biochem. Cell Biol. 2005, 83, 354-364. [CrossRef] [PubMed]

86. Gagné, J.P.; Isabelle, M.; Lo, K.S.; Bourassa, S.; Hendzel, M.J.; Dawson, V.L.; Dawson, T.M.; Poirier, G.G. Proteome-wide identification of poly(ADP-ribose) binding proteins and poly(ADP-ribose)-associated protein complexes. Nucleic Acids Res. 2008, 36, 6959-6976. [CrossRef] [PubMed]

87. Bryant, H.E.; Schultz, N.; Thomas, H.D.; Parker, K.M.; Flower, D.; Lopez, E.; Kyle, S.; Meuth, M.; Curtin, N.J.; Helleday, T. Specific killing of BRCA2-deficient tumours with inhibitors of poly(ADP-ribose) polymerase. Nature 2005, 434, 913-917. [CrossRef] [PubMed]

88. Farmer, H.; McCabe, N.; Lord, C.J.; Tutt, A.N.; Johnson, D.A.; Richardson, T.B.; Santarosa, M.; Dillon, K.J.; Hickson, I.; Knights, C.; et al. Targeting the DNA repair defect in BRCA mutant cells as a therapeutic strategy. Nature 2005, 434, 917-921. [CrossRef] [PubMed]

89. Curtin, N.J.; Szabo, C. Therapeutic applications of PARP inhibitors: Anticancer therapy and beyond. Mol. Asp. Med. 2013, 34, 1217-1256. [CrossRef] [PubMed]

90. Kummar, S.; Ji, J.; Morgan, R.; Lenz, H.J.; Puhalla, S.L.; Belani, C.P.; Gandara, D.R.; Allen, D.; Kiesel, B.; Beumer, J.H.; et al. A phase I study of veliparib in combination with metronomic cyclophosphamide in adults with refractory solid tumors and lymphomas. Clin. Cancer Res. 2012, 18, 1726-1734. [CrossRef] [PubMed]

91. Kummar, S.; Wade, J.L.; Oza, A.M.; Sullivan, D.; Chen, A.P.; Gandara, D.R.; Ji, J.; Kinders, R.J.; Wang, L.; Allen, D.; et al. Randomized phase II trial of cyclophosphamide and the oral poly (ADP-ribose) polymerase inhibitor veliparib in patients with recurrent, advanced triple-negative breast cancer. Investig. New Drugs 2016, 34, 355-363. [CrossRef] [PubMed]

92. Drew, Y.; Ledermann, J.; Hall, G.; Rea, D.; Glasspool, R.; Highley, M.; Jayson, G.; Sludden, J.; Murray, J.; Jamieson, D.; et al. Phase 2 multicentre trial investigating intermittent and continuous dosing schedules of the poly(ADP-ribose) polymerase inhibitor rucaparib in germline BRCA mutation carriers with advanced ovarian and breast cancer. Br. J. Cancer 2016, 114, 723-730. [CrossRef] [PubMed]

93. Michels, J.; Vitale, I.; Galluzzi, L.; Adam, J.; Olaussen, K.A.; Kepp, O.; Senovilla, L.; Talhaoui, I.; Guegan, J.; Enot, D.P.; et al. Cisplatin resistance associated with PARP hyperactivation. Cancer Res. 2013, 73, 2271-2280. [CrossRef] [PubMed]

94. Berger, N.A.; Besson, V.C.; Boulares, A.H.; Bürkle, A.; Chiarugi, A.; Clark, R.S.; Curtin, N.J.; Cuzzocrea, S.; Dawson, T.M.; Dawson, V.L.; et al. Opportunities for the repurposing of PARP inhibitors for the therapy of non-oncological diseases. Br. J. Pharmacol. 2018, 175, 192-222. [CrossRef] [PubMed]

(C) 2018 by the authors. Licensee MDPI, Basel, Switzerland. This article is an open access article distributed under the terms and conditions of the Creative Commons Attribution (CC BY) license (http:/ / creativecommons.org/licenses/by/4.0/). 